\title{
Digitisation of records and archives at two selected state universities in Zimbabwe
}

\author{
Godfrey Tsvuura \\ Zimbabwe Open University \\ tsvuurag@zou.ac.zw or \\ gtsvuura@gmail.com
}

\author{
Patrick Ngulube \\ University of South Africa \\ ngulup@unisa.ac.za \\ http://orcid.org/0000-0002-7676-3931
}

Received: 25 March 2020

Revised: 26 May 2020

Accepted: 28 July 2020

\begin{abstract}
This study focused on the digitisation of records and archives at two selected state universities in Zimbabwe, namely Zimbabwe Open University (ZOU) and Harare Institute of Technology (HIT). The specific objective was to evaluate the legal and statutory frameworks for managing the digitisation of records and archives at the state universities. The legislative and statutory imperatives in Zimbabwe, the exponential growth in digitised records and archiving in the state universities and the lack of capacity of records personnel with regard to the management of digital records and archives, motivated this study. The records of the state universities are stored on network servers that the university can access. However, individual users are often able to copy or move them to individual desktops and portable devices that are beyond the university's control. The study adopted a mixed methods convergent parallel research design and collected data through questionnaires and interviews. The data collection instruments provided both quantitative and qualitative data. Quantitative data were analysed using the SPSS analytical software package, while qualitative data were organised into broad themes and the content reported in narrative form. The findings were that both respondents and participants understand the records management functions in their universities and both state universities are busy creating policies and procedures for the digitisation of records and archives in their business transactions. The findings further indicated that the two state universities were digitising their records and archives using untrained personnel. Legislation, policies, and standards and procedures were not enforced. This exposed the materials to major threats and risks in terms of their integrity, security and authenticity. The study recommended that there the legal and statutory frameworks must be formulated, implemented and enforced to cater for the digitisation of records and archives at state universities in Zimbabwe.
\end{abstract}

Keywords: digitisation, Zimbabwe, legislation, standards, integrity, authenticity

JOURNAL OF SASA

Volume 53, 2020 https://dx.doi.org/10.4314/jsasa.v53i1.2

ISSN: 1012-2796

CSASA 2020 


\section{Introduction}

This study focused on the digitisation of records and archives at two selected state universities in Zimbabwe, namely Zimbabwe Open University (ZOU) and Harare Institute of Technology (HIT). The government of Zimbabwe established these two state universities under the Zimbabwe Open University Act of 1999 [Chapter 25:20] and the Harare Institute of Technology Act of 2005 [Chapter 25:26], respectively. Zimbabwe Open University (ZOU) was established to provide higher education through open and distance electronic-learning (ODeL). The Harare Institute of Technology (HIT) was established as a hub of technology and to deliver quality technology programmes. The two state universities have embraced digitisation of records and archives, which is the process of converting analogue documents into electronic formats through the use of scanner technology. Digitised records and archives are documents created and maintained by means of digital computer technology. They include those that are born digital (created and kept in computers) and those that undergo conversion from paper to digital formats through scanning. The digitisation process has enabled the state universities to provide improved access to information sources, and the preservation and dissemination of information as required, where it is required and at the time it is required. The digitised content is in the form of text, images, audio or multimedia (a combination of text, moving images and audio). This study is premised on the fact that digital records and archives require appropriate management, legislation, policies, procedures and guidelines. They also require the services of trained records personnel, who will be at the heart of the state universities' drive towards digital service delivery. By undertaking this study, the authors wish to underscore why it is necessary for the state universities to understand the concepts of recordkeeping, contextualise it and be able to use digital records and archives for business objectives and strategies. The study provides the background and context to the research, the statement of the problem, the research design, the findings and the recommendations.

\section{Background and context of the study}

In recent years, there has been a growing trend in the adoption of digitisation by universities, as a new strategy for preserving, managing and keeping records and archives. State universities in Zimbabwe play an important role in the socio-economic growth of the country as they adopt the Education 5.0 doctrine, which is teaching, research, community service, innovation and industrialisation. This is driven by technology to innovate and modernise their teaching and learning systems. Under the innovation and industrialisation drives, the state universities are striving to create innovation hubs and industrial parks. In order to satisfy the requirements for modernisation and industrialisation, the state universities have embarked on the digitisation process of their information systems. This, in turn, has led to a demand for appropriate records keeping systems, to keep an account of their activities as institutions of higher learning. However, the success of any digitisation process depends on a well pre-planned and prepared roadmap.

The world over, digitisation of records and archives in state universities has become a phenomenon attributed to rapid technological developments in the 21st century. Technology created the possibilities to improve the quality of services delivery (Mukred, Yusof, Alotabi, Mokhtar \& Fauzi 2019). Asogwa (2013), Asproth (2005) and Chinyemba and Ngulube (2005) agree that the use of 
digitised records and archives has widely been accepted in organisations throughout the world. Today's digital records are superseding traditional paper records, which, similarly, need to be managed and stored for the future (Lewellen 2015). This caused a need for new theoretical records keeping models, international records keeping standards, national records keeping legislation and the rapid development of digital records keeping systems for use in organisations (Lewellen 2015). This has also driven the need for organisations to employ professionals to manage records and archives (Yusof \& Chell 2000). Joseph (2008) notes that the unstructured way in which information on paper and in electronic formats is captured, such as e-mails, word processors and spreadsheets, signifies the beginning of the digital records and archives revolution. Governments and organisations around the world have begun to introduce and implement electronic documents and records management systems (EDRMS) and have enacted laws to cater for digital records and raising their importance at regulatory and national levels (Lewellen 2015).

The ability of any organisation to collect, store and use records and archives has important consequences for its performance (Olivera 2000). Higher education institutions face unique challenges when implementing computer-based information management systems (Mukred et al. 2019). It is a common fact that idiosyncratic software systems generate, manage and store digital data using proprietary technologies and media that are not developed to segregate records from other types of information (Duranti 2010). In spite of these problems, the state universities in Zimbabwe are digitising their records and archives, using idiosyncratic software systems, with the assistance of records staff, who are not trained in the digitisation process. Perry (2014) points out that using records staff who have not been formally trained in digital activities will result in risky and bad outcomes.

\section{Benefits of digitisation in universities}

Digitisation has brought in a new dispensation with a great deal of changes in modernising business processes, communication, financial management and decision making (Asogwa 2013). Managing records and archives is a symbiotic element of any organisation, as it promotes accountability and transparency, and enable organisations to meet goals and objectives (Phiri 2016). Digital records keeping in state universities is one of the drivers of modernisation, and it needs to be promoted and embedded in their strategic plans as any strategy without records keeping, is bound to be inadequate and fraught with difficulties.

Universities worldwide, as institutions of higher learning, have been in existence for more than 900 years, since the establishment of the University of Bologna in 1088 (Phiri 2016). Their functions, as Perkin (2007) states, have undergone transformation - from that of teaching and preserving established culture, to that of teaching and research - in modern dispensations and digital revolution. This requires of state universities to operate in an environment where there are laws and regulations that govern records keeping requirements, such as the need to create specific types of records and to keep records for specific lengths of time (McLeod \& Hare 2006). 
Records must be trustworthy for an organisation to rely on them to meet its legal and business requirements (NARA 2005; Cullen et al. 2000). According to Mukred et al. (2019:3), management of records and archives carries several advantages, including the following:

1) E-records can reduce the volume of data and declutter the data storage area: data can be archived offsite for safe storage - this will allow some organisations to reduce their storage space requirements by up to $40 \%$.

2) Rapid retrieval of information: successful systems can expediently retrieve information this allows for the provision of superior customer service.

3) Legal compliance and mitigation with regard to litigation risks: an effective records management system safeguards the organisation from litigation and legal investigations an electronic records management system should serve as a safety net for organisations against dangers and pitfalls.

4) An electronic records management system minimises human errors, ensures data security, facilitates access to information, duplicates documents, provides data documentation, reduces information and communication technologies costs, supports decision-making activities, enhances quality, serves as a data repository and minimises the use of paper.

5) An electronic records management system clarifies information, enables timely delivery, reduces storage space and ensures easy data access and data sharing of information.

\section{Statement of the problem}

In Zimbabwe, state universities' records are exposed to high risks, threats and adverse effects and they can get lost, without a trace. Literature has indicated some constraints in the digitisation process, including issues of policy, procedures, finances and lack of technical skills (Asogwa 2012; Mukred \& Yusof 2015; Mukred et al. 2019). Studies by these authors attest to the growing imperative for digitisation of records and archives. Although countries have improved their laws to meet digitisation demands, the legislation governing the management of records and archives in Zimbabwe has not been updated to reflect the current technological developments. This deficiency in legislative and digital records management policies has resulted in official digitised records being produced and stored on systems outside the state universities ownership. Given the absence of dynamic legislative and policy requirements, the records are exposed to major threats and risks such as being tampered with, being used unofficially or lost in the abyss of the internet and social media. The legislative and policy imperatives and the exponential growth of these materials have resulted in the real threat of information being lost. Asogwa (2012) and Mukred et al. (2019) point out that African countries rarely have legislation dealing with electronic records (e-records) and electronic archives (e-archives) management; hence, they are unable to manage such records effectively. Effective legislation and policies are required to ensure the systematic, effective and efficient management of records and archives at state universities. The management of digital records and archives at state universities must adhere to laws and regulations. Therefore, the absence of such would render them unable to retain records and archives for future use.

The major objective of this study is to evaluate the legal and statutory frameworks for managing digitised records and archives at state universities and to determine the levels of professional 
training of the records personnel at these institutions. The research questions were formulated as follows:

- What are the legal and statutory frameworks for digitisation of records and archives at state universities?

- Are there gaps in the professional training of records personnel regarding the digitisation of records and archives?

\section{Literature review}

A lack of comprehensive policy frameworks on the management of digital records has been cited as a major impediment to adequate digital records management (Kemoni 2009; Iwhiwhu 2010). Asogwa (2012) and Mukred et al. (2019) point out that African countries, including Zimbabwe, rarely have legislation dealing with electronic records (e-records) and electronic archives (earchives) management. The National Archives of Zimbabwe Act of 1986 was promulgated to govern records management in the country. Although the Act defines "records" as documents in any media, it does not address issues of digitisation of records and archives. Mutsagondo and Chaterera (2016) note that records and archives professionals in Zimbabwe are currently using the National Archives Act of 1986 to guide policy regarding the management of digital records, in the absence of any legal provision that explicitly provides for digital records. Similarly, there is a lack of institution-wide digital records management policies and procedures in developed countries such in the United States and Canada, as revealed by Schina and Wells (2002).

Wamukoya and Mutula (2005) bemoan the fact that digitised records management in the East and Southern Regional Branch on International Archives (ESARBICA) has posed a number of problems and challenges that include, but is not limited to, the following: lack of skills and competencies; inadequate resources; lack of awareness among government authorities and records professionals; fragility of media; and the need for specialised storage. Asogwa (2013) reveals that universities in Nigeria do not have basic records management policies for managing ordinary records. Zimbabwe is yet to make a realistic effort and commitment to embark on digitisation (Sigauke \& Nengomasha 2011). Fayol (2016) argues that the lack of advanced technological systems and upgrading of related infrastructure is a serious challenge to digitisation, especially in Africa. A lack of advanced technology in Zimbabwe has been a major hurdle to the full implementation of digital technology (Guzuma 2017). This can be attributed to the economic meltdown, existing systems and technologies that are outdated, and the lack of significant financial resources to support and install digital technology (Guzuma 2017).

Another obstacle is a lack of experts in the digital industry to help install digital technology in Zimbabwe. Many Zimbabwean technology experts have moved abroad to countries like South Africa, Botswana, United Kingdom, United States and Canada, in search of greener pastures - the "brain drain" phenomenon (Guzuma 2017). That resulted in a serious shortage of technology experts to help digitise the country.

Wamukoya and Lowry (2013) set out the basic elements that must be in place at national level for managing public sector records and they include: legislation, policy, standards, procedures, 
staffing, infrastructure and facilities, and capacity building (training). Asogwa's (2013) framework for the management of digitised records and archives include the following: a records policy statement; records legislation; records standards practices; guidelines and manuals; codes of best practices; and training, services and support. One of the first critical steps in managing digitised records and archives is for top management to ensure the existence and implementation of a legislative and regulatory framework for proper records management (Asogwa 2013). According to the Government Records Services (2011), good records management starts with a policy that reflects an organisation's needs, with an objective to create and manage authentic, reliable, complete and usable records that are capable of supporting the business functions and activities of an organisation. Smith (2008) laments that organisations should have a records management policy statement in place that is endorsed by top management and made available to all staff. Smith (2008:3) alludes to the fact that the records management policy framework should provide a records keeping system that will:

- meet the organisation's business needs

- address the needs of the organisation's stakeholders

- conform to relevant legislation, regulations and standards

- provide a basis for accountability

- identify responsibilities for records personnel

However, Taylor (2000) and Mnjama and Wamukoya (2007) observe that the lack of attention to records management in state universities can be attributed to a lack of coordinated and planned programmes, and the absence of policies, procedures and facilities for managing records within the institutions. Asogwa (2012:201) states that problems in managing digitised records and archives at universities are administrative/management-induced challenges as well as challenges imposed by information technology such as weak legislative and organisational infrastructures; inadequate ICT skills and competences; increased use of information technologies in records management; low levels of ICT literacy; corruption or inadequate financial resources; political instability; poor funding; constantly changing technology and applications; deterioration of digital media, among others. Mnjama and Wamukoya (2007) highlight that the mere existence of a law or policy is not enough evidence that an organisation is committed to manage digitised records and archives. Griffin (2003) observes that in many governments, policies and guidance for managing records are non-existent and the legislative and regulatory framework is often weak and outdated.

\section{Research methodology}

The study adopted a mixed research convergent parallel approach, whereby both quantitative and qualitative techniques were used. This was meant to minimise the weaknesses of the mono-method approach. Both quantitative and qualitative data provided the researchers with different types of data that yielded positive results. Creswell and Hirose (2019) argue that the idea to mix both quantitative and qualitative data provides a more complete understanding than either method on its own. This mixed research approach in a single study has been widely supported by scholars (Mayoh \& Onwuegbuzie 2015; Dewasiri, Weerakoom \& Azeez 2018). The researchers used mixed methods research in the collection and analysis of the data, which means mixing qualitative 
and quantitative data in a single study, as supported by Wium and Louw (2018). This method helped the researchers to explore evidence from both quantitative and qualitative data. This choice was also informed by Tashakkori and Teddlie (2003), Ngulube (2019; 2020), Creamer, (2018) and Gail (2013), who reiterate that a truly mixed methods approach incorporates multiple approaches in all stages of the study. The mixed methods convergent parallel design is the most familiar of the basic mixed methods strategies, as it consists of combining quantitative and qualitative data (Creswell 2014; Creswell \& Plano Clark 2018; Ngulube 2019; 2020). In line with an advice from Creswell and Plano-Clark (2011), the integration for the current study occurred at the design level and during interpretation as the convergent parallel approach entails that the researcher concurrently conducts the quantitative and qualitative elements in the same phase of the research process and weighs the methods equally and analyzes the two independently and interprets the results together.

\section{Data findings and presentation}

The objective was to evaluate the legal and statutory requirements frameworks for managing the digitisation of records and archives. The respondents, who were issued with questionnaires, were asked whether they were creating digital records in performing their work.

\subsection{Results from the questionnaire}

The purpose for creating records, regardless of their physical characteristics, is to document transactions and provide essential evidence of organisational decisions. Penn, Pennix and Coulson (1994) and Shepherd and Yeo (2003) state that the prime objective of records creation is to ensure that only records needed by the system are created. Khumalo and Chigariro (2017) conclude that records, created as a result of any given organisation's day-to-day business transactions, are assets that have to be managed satisfactorily. Furthermore, Ohio State University (2010) holds that universities must have an understanding that, whatever records they create or receive, whether paper or electronic, must be well managed. Respondents were asked whether their universities were creating digital records. The study established that the $32(100 \%)$ respondents from the two state universities were creating digital records, as indicated on the table 1 below.

Table 1. Creation of records and archives

\begin{tabular}{|l|l|l|}
\hline \multicolumn{1}{|c|}{ Name of university } & Number of respondents & Percentage \\
\hline Zimbabwe Open University & 20 & 63 \\
\hline $\begin{array}{l}\text { Harare Institute of } \\
\text { Technology }\end{array}$ & 12 & 37 \\
\hline Total & 32 & 100 \\
\hline
\end{tabular}

ISO 15489-1:2001 (ISO 2001) states that records management policies and procedures ensure that appropriate attention and protection is given to all records and that the evidence and information they contain can be retrieved more efficiently, using standard practices and procedures. On the legal and regulatory frameworks governing digital records management, the respondents were 
asked whether they were aware of the policies that govern digital records creation. Of the 32 respondents, $16(50 \%)$ indicated that they were aware, while $14(44 \%)$ were unaware and $2(6 \%)$ were undecided. The findings imply that not all records personnel were aware of the existing policies and regulatory frameworks.

Mutsagondo and Ngulube (2018) hold that there is need for personnel managing digital records to be equipped with a variety of skills, which include general records management skills, information technology skills, management skills, software engineering skills, preservation skills, information systems skills and office systems skills. The respondents were asked to indicate whether they were trained to manage digital records and archives. Of the 32 respondents, $8(25 \%)$ indicated that they had no training, $13(41 \%)$ indicated that they had training, while $10(31 \%)$ were not aware and 1 (3\%) was undecided. The study established that a larger number of the respondents (19:58\%) were not trained in digital records management, as indicated by figure 1 .

\section{Trained in managing digitised records}

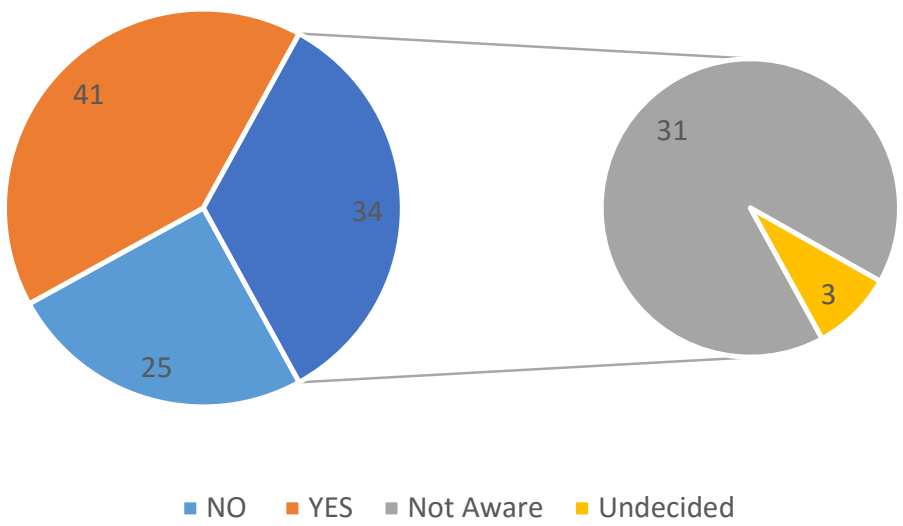

Figure 1: Training in managing digitised records

\subsection{Findings from the interviews}

The participants were asked to clarify the policies and regulations that guide the work of their universities. Participants from ZOU indicated that they were guided by the Zimbabwe Open University Act of 1999 (Chapter 25:20), the National Archives of Zimbabwe Act of 1986 and the guidelines from the International Standardization Organisation (ISO 15498 of 2001). The participants revealed that ZOU has developed two internal policies, the e-mail records management and the digitisation policies, in 2016. In this regard, one participant from ZOU said:

Apart from the legislation and the international standards, the university crafted the digitisation policy and e-mail records management policy in 2016 to guide the work of the university. In addition, there is an existing records committee of Senate, which sits from time to time, 
deliberating on records management issues and they report to the Senate, which is the highest decision-making board of the university.

A participant from HIT reported that their university uses the Harare Institute of Technology Act of 2005 as their guiding legal instrument. Participants from this institution were quick to point out that they are working on the development of a records management policy framework, which would cover the issues of digital records management, e-mail records management, document imaging and web content imaging. One participant had this to say:

Currently, the records management policy framework is being worked on and, once that policy is in force, it will regulate the management of the university digital records and archives. The e-mail policy is operational, as all influential staff members use the university e-mail accounts. This makes it easy to control the university e-mail records and archives.

The participants were further asked to provide more clarification regarding the enforcement of policies and legislation. In this regard, one participant from ZOU commented thus:

Both the digitisation and e-mail records management policies were not effectively implemented. There is a need for enforcement and management support. The current status is that the university e-mail platform is not working and individuals are using g-mail and Yahoo accounts, rendering the e-mail records prone to individual ownership, as they will be in private mailboxes.

One participant from HIT made the following comment: All influential members of staff are using the organisational e-mail and it is to control all the records.

The participants were asked to elaborate on whether records personnel had the required training and skills to manage digitised records and archives. Participants from ZOU said that records personnel working in the registry received on-the-job training, especially on the handling of organisational records. One participant from ZOU said Some personnel in the records sections have degrees that have nothing to do with records management and this has a negative impact on proper recordkeeping, let alone digitisation. Another participant from HIT made this remark with regard to training: Mostly, they have received on-the-job training by being guided in the handling of students' records.

\section{Discussions}

The study established that ZOU has the policies that are in line with the legal and statutory requirements, but lacks enforcement of the policies, while HIT is in the process of establishing policies for the digitisation of records and archives. Luyombya (2010) holds that formal instruments such as policies and regulations are the key determining factors for the successful creation and management of digitised records and archives. Parer (2001) determined that a legal and regulatory framework is critical, as it reflects how an organisation intends to manage its records and archives. The findings in this study indicate that there is a lack of enforcement and implementation of the legal and regulatory frameworks for the management of digitised records 
and archives at ZOU. A lack of enforcement and implementation of records management legislation and policies was also observed by Luyombya (2010) in the Ugandan public service, where the law was not endorsed by application and implementation of policies and procedures to guide all staff members, thereby making it difficult to enforce. Based on the findings, ISO (15489:2001) articulates that all organisations need to identify and observe the legal and regulatory environment that affect their activities and comply with the requirements to document such activities.

The findings also indicated that the situation on policy and regulatory frameworks in the two state universities reflect what is happening across the ESARBICA region (Okello-Obura 2012; Kemoni 2009; Wato 2006; Mutiti 2001), where policy and regulatory issues are not given top priority. Mutsagondo and Tsvuura (2017) hold that, if there are no policies, records practitioners will be caught between a rock and a hard place, as they juggle between options of how they should professionally manage such records. The authors (Mutsagondo \& Tsvuura 2017) note the dilemma regarding the management of digital records and archives, namely: the regulatory and legal framework governing digital records and archives management in Zimbabwe is in shambles.

The National Archives of Zimbabwe Act of 1986 does not adequately cover the management of digital records and archives, as stated by Dube (2011), Mutsagondo and Chaterera (2016) and Huni and Dewah (2019). In order to determine the level of professional training among records staff, Netshakhuma (2016) holds that digitisation is a new challenge, which requires technical skills and knowledge. Tsvuura and Mutsagondo (2015) emphasise that institutions must identify the characteristics of the knowledge and skills required by individual staff members that would capacitate them to undertake their duties and responsibilities effectively.

\section{Conclusion and recommendations}

This study established that the two state universities are at different levels in the enforcement and implementation of digital records and archives management policies. Digital records should be managed within a legal framework under the tutelage of skilled personnel to uphold the cultural (or historical) value of these records, as envisaged in the records continuum theory, and to maintain the evidential value (i.e. digital diplomatics) thereof. The study concluded that the two state universities should implement and enforce policies on records management and use trained personnel to create and manage digitised records and archives. In view of the findings, this study recommends that:

1. ZOU should implement and enforce policies to enable the proper creation and management of digitised records and archives. The enforcement of the law and regulations is critical for compliance and sound digital records keeping. An accountable records keeping system entails that there should be a unified framework of identified policy objectives and implementation directives. The enforcement of the law also requires a paradigm policy shift to accommodate both records keeping and archiving in a holistic way at national level, since the regulatory authority (National Archives of Zimbabwe) is also still a baby in the management of digitised records and archives. The National Archives of Zimbabwe Act of 1986 is outdated, especially 
on issues of digitisation of records and archives, as it does not directly address such. Therefore, there is a need to consider its amendment or repeal.

2. HIT should soon put in place relevant policies that govern digitised records and archives. This would enable the institution to enforce and implement appropriate policies for the better creation and management of digitised records and archives.

3. Both state universities should invest in the training of records and archives personnel, so that they have appropriate skills and knowledge to create and manage digitised records and archives.

\section{References}

Asogwa, E.B. 2013. The readiness of universities in managing electronic records. The Electronic Library 31(6): 792-807.

Asogwa, E.B. 2012. The challenge of managing electronic records in developing countries. Records Management Journal 22(3): 198-211. DOI.org/10.1108/09565691211283156

Asproth, V. 2005. Information technology challenges for long-term preservation of electronic records. International Journal of Public Information Systems 1: 27-37.

Chinyemba, A. \& Ngulube, P. 2005. Managing records at higher education institutions: a case study of the University of KwaZulu-Natal, Pietermaritzburg Campus. South African Journal of Information Management 7(1). http://general.rau.ac.za/infosci/raujournal/default.asp?to=peervol7nr1 (Accessed 25 August 2015).

Creamer, E.G. 2018. An introduction to fully integrated mixed methods research. Los Angeles, CA: Sage.

Creswell, J.W. 2014. Research design: qualitative, quantitative and mixed methods approaches. $4^{\text {th }}$ ed. London: Sage.

Creswell, J.W. \& Hirose, M. 2019. Mixed methods and survey research in family medicine and community health. Family Medicine and Community Health 2019(7): e000086. DOI:10.1136/fmch-2018-000086

Creswell, J.W. \& Plano, Clark, V.L. 2011. Designing and conducting mixed methods research. Thousand Oaks, CA: Sage Publications.

Creswell, J.W. \& Plano Clark, VL. 2018. Designing and conducting mixed methods research. $3^{\text {rd }}$ ed. Thousand Oak, CA: Sage.

Cullen, C.T., Hirle, P.B., Levy, D., Lynch, C.C \& Rothenbrg, J. 2000, Authenticity in the digital environment, Washington DC: Council on Library and Information Resources. http://www.clir.org (Accessed 12 November 2019).

Dewasiri, N.J., Weerakoom, Y.K.B. \& Azeez, A.A. 2018. Mixed methods in finance research: the rationale and research designs. International Journal of Qualitative Methods 17: 1-13.

Dube, T. 2011. Archival legislation and the challenge of managing archives in Zimbabwe. ESARBICA Journal 30: 279-290.

Duranti, L. 2010. Concepts and principles for the management of electronic records, or records management theory is archival diplomatics. Records Management Journal 20(1): 78-95.

Fayol, S. 2016. Africa and the digital world. London: Cambridge University Press. 
Gail, D.C. 2013. Demystifying mixed methods research designs: a review of the literature. Mevlana International Journal of Education 3(2): 112-122.

Government of Zimbabwe. 2005. Harare Institute of Technology Act [Chapter 25:26] Harare: Government Printers.

Government of Zimbabwe. 1986. The National Archives of Zimbabwe Act, [Chapter 25:06] Harare: Government Printers.

Government of Zimbabwe. 1999. Zimbabwe Open University Act [Chapter 25:20] Harare: Government Printers.

Government Records Services 2011. Good records management practices. Available at http://www.grs.hk/ws/english/engimages/grmp_e.pdf (Accessed 2 January 2020).

Griffin, A. 2003. Managing records in the electronic age. London: International Records Management Trust (IRMT).

Guzuma, G. 2017. Digitisation: an emerging first-rate practice in records management. Oxford: Oxford University Press.

International Standard Organisation (15489-1) 2001. International Standard: Information and documentation - records management - Part 1: General, International Organization for Standardization. Geneva.

Huni, P. \& Dewah, P. 2019. Admissibility of digital records as evidence in Bulawayo High Court in Zimbabwe. Journal of the South African Society of Archivists 52: 133-148.

Iwhiwhu, B.E. 2010. Electronic records management in Africa. Problems and prospects, in Handbook of research on information communication technology policy: trends, issues and advancements. Edited by E. Adomi. PA. Hershey: 161-165.

Joseph, P. 2008. EDRMS 101: The basics. RM Information and Records Management Annual 26: 10-26.

Kemoni, HN. 2009. Management of electronic records. Records Management Journal 19(3): 190203. DOI org/10.1108/09565690910999184

Khumalo, N.B. \& Chigariro, D. 2017. Making a case for the development of a University Records and Archives Management Programme at the National University of Science and Technology (NUST) in Zimbabwe. Journal of the South African Society of Archivists 50: 67-78.

Lewellen, M.J. 2015. The impact of the perceived value of records on the use of electronic recordkeeping system. PhD thesis, Victoria University of Wellington. Available at: https://core.ac.uk/download/pdf/41339424pdf (Accessed 23 January 2020).

Luyombya, D. 2010. Framework for effective public digital records management in Uganda. $\mathrm{PhD}$ thesis, University College of London. http://www.discovery.ucl.ac.uk/19354/1/19354.pdf (Accessed 16 December 2019).

Mayoh, J. \& Onwuegbuzie, A.J. 2015. Toward a conceptualisation of mixed methods phenomenological research. Journal of Mixed Methods Research 9: 91-107.

McLeod, J. \& Hare, C. 2006. How to manage records in the e-environment? $2^{\text {nd }}$ ed. London: Routledge Taylor and Francis Group.

Millar, L. \& Roper, M. 2009. Preserving electronic records: Training in electronic records management. London: IRMT.

Mnjama, N. \& Wamukoya, J. 2007. E-government and records management: an assessment tool for e-records readiness in government. The Electronic Library 25(3): 274-284. 
Mukred, M. \& Yusof, Z.M. 2018. The performance of educational institutions through the electronic records management systems: factors influencing electronic records management system adoption. International Journal of Information Technology Project Management 9(3): 35-51.

Mukred, M., Yusof, Z.M., Alotabi, F.M., Mokhtar, U. \& Fauzi, F. 2019. The key factors in adopting an electronic records management system in the educational sector: A UTAUTBased Framework. IEEE Access 7: 35963-35980.

Mutiti, N. 2001. The challenges of managing electronic records in the ESARBICA region. ESARBICA Journal 21(1): 57-61.

Mutsagondo, S. \& Chaterera, F. 2016. Mirroring the National Archives of Zimbabwe Act in the context of electronic records: lessons for ESARBICA member states. Information Development 32(3): 254-259.

Mutsagondo, S. \& Ngulube, P. 2018. Skills impact assessment of personnel managing electronic records in Zimbabwe's Public Service. Mousaion 36(2): 1-19.

Mutsagondo, S. \& Tsvuura, G. 2017. Dilemma in disposing electronic mail records in public departments: the Zimbabwean Scenario. Paradigms: A Research Journal of Commerce, Economics and Social Sciences 11(2): 190-195.

NARA. 2005. US national archives and records administration guidance on managing web records: what are the characteristics of trustworthy records? Available at: http://www.archives.org/records-mgnt/policy/managing-web-records.html (Accessed 12 November 2019).

Netshakhuma, N.S. 2016. An exploration of the digitization strategies of the liberation archives of the African National Congress in South Africa. MINF dissertation, University of South Africa.

http://uir.unisa.ac.za/bitstream/handle/10500/22011/dissertation_netshakhuma_ns.pdf (Accessed 20 December 2019).

Ngulube, P. 2020. The movement of mixed methods research and the role of information science professionals. Handbook of research on connecting research methods for information science research. Edited by P. Ngulube. Hershey, PA: IGI Global: 425-455.

Ngulube, P. 2019. Mapping methodological issues in knowledge management research 20092014. International Journal of Knowledge Management 15(1): 85-100.

Ngulube, P. 2015. Trends in research methodological procedures used in knowledge management studies (2009-2013) African Journal of Library, Archives and Information Sciences 24(2): 125-143.

Ngulube, P. \& Ngulube, B. 2015. Mixed methods research in the South African Journal of Economic and Management Science: An investigation of trends in the literature. SAJEMS 18(1): 1-13.

Ohio State University. 2010. Records management university archives. Columbus: Ohio State University.

Okello-Obura, C. 2012. Records and information management as a catalyst for fighting corruption. Information Development 29(2): 114-122.

Olivera, F. 2000. Memory systems in organisations: an empirical investigation of mechanisms for knowledge collection, storage and access. Journal of Management Studies 37(6): 811-832. 
Parer, D. 2001. Archival legislation for commonwealth countries. London: Association of Commonwealth Archivists and Records Managers (ACARM). Available at: http://www.acarm.org/publications/Legislationpdf (Accessed 11 September 2017).

Perkins, H. 2007. History of universities. London: Springer.

Perry, S.R. 2014. Digitisation and digital preservation: a review of the literature. SLIS Student Research Journal 4(1)(4): 1-13. http://scholarworks.sjsu.edu/s/issrj/vol4/iss1/4 (Accessed 12 January 2016).

Penn, I.A., Pennix, G.B. \& Coulson, J. 1994. Records management handbook. $2^{\text {nd }}$ ed. Vermont: Gower Publishers.

Phiri, M.J. 2016. Managing university records and documents in the world of governance, audit and risks: case studies from South Africa and Malawi. PhD Thesis, University of Glasgow. Available at: https://eleanor.lib.gla.ac.uk/record=b3165766 (Accessed 20 October 2019).

Schina, B. \& Wells, G. 2002. University archives and records programmes in the US and Canada. Archival Issues 27(1): 35-52.

Shepherd, E. \& Yeo, G. 2003. Managing records: a handbook of principles and practice. Facet Publishing: London.

Sigauke, D.T., \& Nengomasha, C.T. 2011. Challenges and prospects facing the digitisation of historical records for their preservation within the National Archives of Zimbabwe. Paper presented at the 2nd International Conference on African digital libraries and archives (ICADLA-2) at the University of Witwatersrand, Johannesburg, South Africa, 14-18 November.

https://www.google.com/search?client=firefox-b$\mathrm{d} \& \mathrm{q}=$ sigauke+and+nengomasha+2011+paper (Accessed 30 November 2019).

Smith, K. 2008. Public sector records management: a practical guide. Abingdon: Ashgate Publishing Group.

Tashakkori, A. \& Teddie, C. (eds) 2003. Handbook mixed methods in social and behavioural research. Thousand Oaks, CA: SAGE.

Taylor, M. 2000. Records management at tertiary institutions in the SCECSAL region at the dawn of the new millennium, in Information 2000: a vision for the SCECSAL region. Edited by Chisenga, J., Chitambo, A. \& Onyango, F. Windhoek: Namibian Information Workers Association: 239-245.

Tsvuura, G. \& Mutsagondo, S. 2015. The role of tertiary education institutions in the development of records and archives management discipline in Zimbabwe. International Journal for English and Education 4(2): 458-470.

Wamukoya, J. \& Kemoni, H. 2001. Educating recordkeeping professionals in Africa: the case of Moi University, Kenya. ESARBICA Journal 20: 41-48.

Wamukoya, J. \& Lowry, J. 2016. Integrity in government through records management essay in honour of Anne Thurston. Milton Park: Routledge.

Wamukoya, J. \& Mutula, S.M. 2005. E-records management and governance in East and Southern Africa. Malaysian Journal of Library and Information Science 10(2): 67-83.

Wato, R. 2006. Electronic records readiness in the ESARBICA region: challenges and the way forward. ESARBICA Journal 25: 69-83. 
Wium, A.M. \& Louw, B. 2018 Mixed methods research: a tutorial for speech-language therapists and audiologists in South Africa. South African Journal of Communication Disorders 65(1):a573. DOI.org/10.4102/sajcd.v65i1.573.

Yusof, Z. \& Chell, R. 2000. The records lifecycle: an inadequate concept for technology generated records. Information Development 16(3): 135-141. 